\title{
Evidence for scavenging by the marine crocodile Metriorhynchus on the carcass of a plesiosaur
}

\begin{abstract}
Richard Forrest
FORREST, R. 2003. Evidence for scavenging by the marine crocodile Metriorhynchus on the carcass of a plesiosaur. Proceedings of the Geologist's Association, 114, 363-366. A specimen of the long-necked plesiosaur Cryptoclidus from the Oxford Clay of Peterborough bears tooth marks on its cervical vertebrae which show that is was the object of post-mortem scavenging by the marine crocodilian Metriorhwnchus. This extends the behavioural range of Metriorhynchus below surface waters and shows that it was an opportunistic scavenger capable of diving to the sea floor.
\end{abstract}

Earth Sciences Department, New Walk Museum, 55 New Walk, Leicester LEI 7 EA and Department of Geology, University of Leicester. University Road, Leicester LEI 7RH (Address for correspondence: 3 Chestnut Grove, Radcliffe-on-Trent. Nottingham NGI2 $1 \mathrm{AH}$. UK)

\section{INTRODUCTION}

The Oxford Clay in the area around Peterborough in eastern England has been a rich source of vertebrate fossils, especially marine reptiles, for over two hundred years. Public and private collections contain several thousand specimens, most commonly as isolated elements or small associated assemblages, but occasionally as substantially complete and articulated skeletons (Martill, 1986a; J. Liston, pers. comm.).

The marine reptile fauna was dominated by plesiosaurs, marine crocodiles and ichthyosaurs (Andrews, 1910-1913; Martill et al., 1994). Plesiosaurian genera include the long-necked Cryptoclidus (Phillips, 1871), Muraenosaurus (Seeley, 1874) and Tricleidus (Andrews, 1909), the short-necked forms Peloneustes (Seeley, 1869), Liopleurodon (Sauvage, 1874), Simolestes (Andrews, 1909) and the recently described manatee-like Pachycostasaurus (Cruickshank et al., 1996).

The two genera of marine crocodile, Metriorhynchus (Deslongchamps, 1863-1869) and Steneosaurus (Deslongchamps, 1863-1869) were redescribed by Adams-Tresman (1987a, b). A single genus of ichthyosaur, Ophthalmosaurus is also recorded.

Much of the material available for study is held in public collections in Peterborough. London, Leicester, Glasgow, Oxford and Tübingen, Germany, though a large amount is to be found in other collections not only in the UK but in other parts of the world. The quantity and quality of the material available to researchers is a huge and rather under-used resource.

\section{MATERIAL}

The material catalogued as R54 is stored in three boxes in Peterborough Museum and represents at least two specimens of plesiosaur, distinguishable by their different ontogenetic ages. A series of six dorsal vertebrae cannot be confidently matched to either set and may represent a third individual. The individual which forms the subject of this paper has been designated R54(B). Notes on the identification of the three probable individuals under the catalogue reference $\mathrm{R} 54$ are kept with the specimen.

\section{Elements represented}

Fragment of maxilla, bearing single broken tooth; isolated broken tooth; fragment lower jaw consisting of partial articular and fragment of surangular; right scapula; atlas/axis with partial neural arch; 12 cervical centra; one pectoral centrum; seven dorsal centra; six more-or-less complete dorsal neural arches; fragment from base of right side of a pectoral neural arch: five cervical ribs; three fragmentary posterior cervical or dorsal ribs, one almost complete; a small fragment of bone, possibly a zygapophysis is attached to one of the dorsal ribs; eight fragments of gastral ribs: indeterminate bone fragment.

Specimen R54(B) can be confidently assigned to the genus Cryptoclidus on the basis of the redescription of the genus by Brown (1981). Although most of the tip of the tooth is missing, six shallow widely spaced ridges can be distinguished on the lingual side. The spacing of the alveoli on the maxillary fragment corresponds closely to that of the composite skull reconstruction. Vertebral dimensions correspond fairly closely with those given for a juvenile Cryptoclidus (Brown, 1981). 


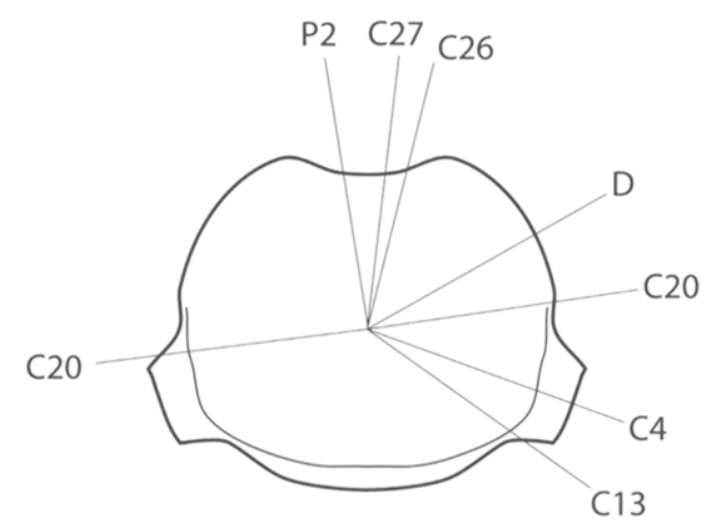

Fig. 1. Diagrammatic representation of position of bite locations relative to anterior articular face of centrum

Twenty-three cervical vertebrae are preserved. Missing vertebrae were identified by comparing vertebral proportions with those of the substantially complete specimen of Cryptoclidus eurymerus. BMNH R2680. The missing vertebrae are numbers $6,10,14,15,19,31$ and 32, counting atlas and axis as numbers 1 and 2 .

The vertebral column of R54(B) shows a series of bite marks. The right neural arch fragment articulates neatly onto one of the dorsal centra. but is distorted by a bite mark on one side. Several of the centra bear bite marks on the articular rims, predominantly on the animal's left dorsal side (Fig. 1).

\section{DISCUSSION}

The location of the bite marks suggests limited access to the carcass, possibly because it was lying in a soft sea-floor substrate as has been proposed for the Oxford Clay sea (Martill, 1993). Most of the marks are on the articular rims of the centra, suggesting that the biter had the leisure to avoid damage to its teeth by feeling carefully for the gaps between the centra before applying pressure, rather than lunging for the passing neck of a living animal. Both observations are consistent with post-mortem scavenging rather than primary predation.

A tooth mark on the $20^{\text {th }}$ cervical vertebra (Fig. 2) shows a pattern of striations which correspond in spacing to the ridges on the teeth of the marine crocodilian Metriorhynchus, a tooth of which is shown at the same scale for comparison (LEICS G418.1956.27.4). The profile of the bite matches the laterally compressed profile of the Metriorhynchus tooth. A smaller mark on the same centrum is probably the contralateral element of the same bite.

Other marine vertebrates capable of leaving bite marks of this size can be eliminated on the basis of the radius of the profile of the bite and the size and spacing of the striations. In marine reptile fauna only the teeth of the large pliosaurs Liopleurodon and Simolestes

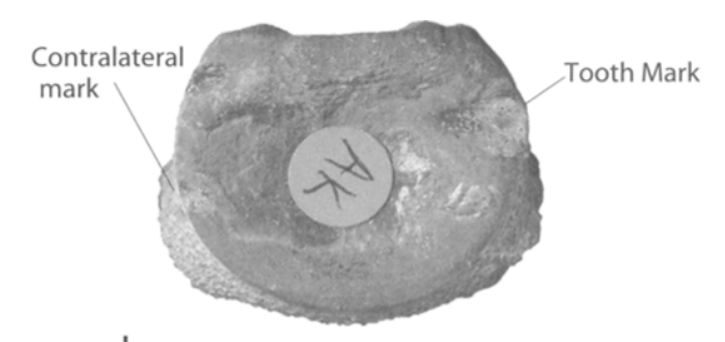

Scale bar $10 \mathrm{~mm}$

Width of centrum $38 \mathrm{~mm}$

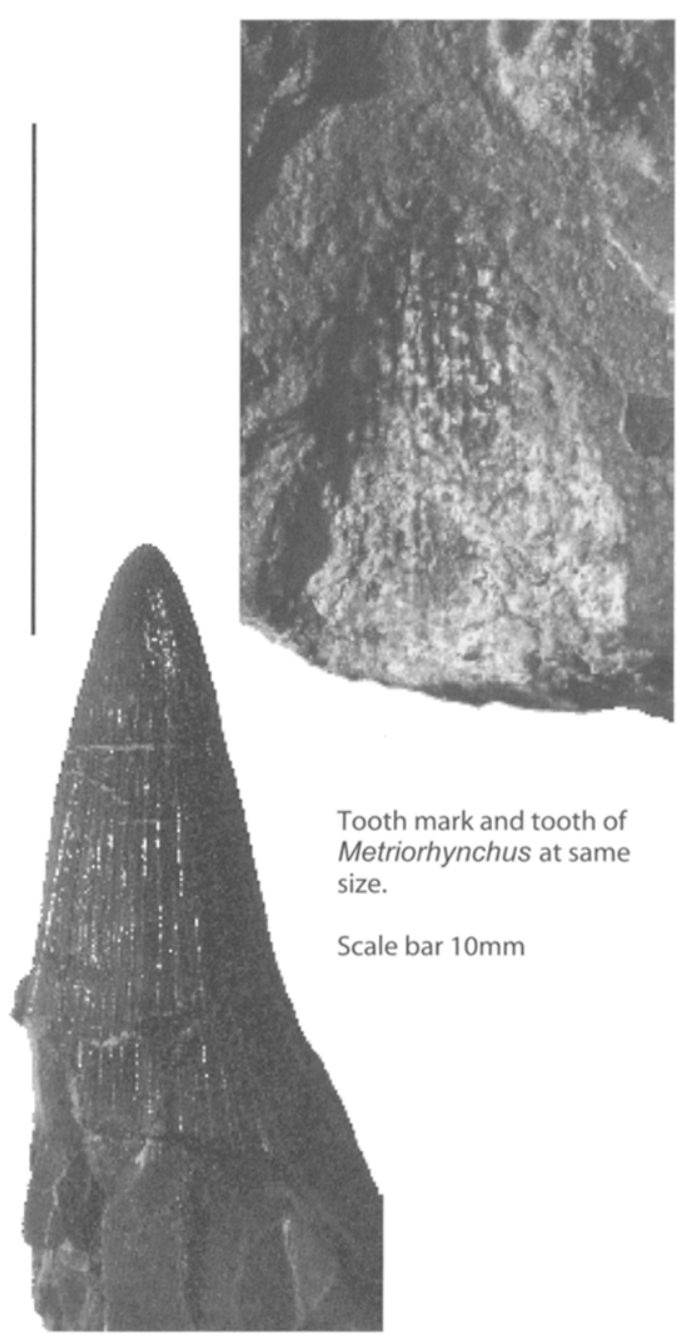

Fig. 2. Bite marks on 20th cervical centrum of PET.R.54.(B) (Cryptoclidus of. C. eurvmerus). Tooth of LEICT G.418.1956.27 (Meriorhynchus sp.) for comparison.

could leave marks of similar radius. However, those of Liopleurodon has have much more widely spaced and coarser striations, and those of Simolestes are only lightly decorated, especially towards the tip. 
No records of collection are associated with the specimen and the possibility that these marks are caused by taphonomic processes, such as pressure from overlying skeletal elements, cannot be entirely excluded. The form of some of the marks as scratches penetrating the surface of the bone and still partly filled with matrix makes a taphonomic origin very unlikely and, in others, the clearly defined striations cannot be matched to the surface decoration of skeletal elements such as ribs.

Hua (1994) characterizes Metriorhynchus as a nearsurface hunter on cephalopods on the basis of morphofunctional analysis. Martill (1986b) reported on the stomach contents of a specimen which included belemnite hooklets and describes it as an opportunistic carnivore. Pterosaur bones reported in this paper have since been identified as fish bones (D. Unwin. pers. comm.)

The teeth of Metriorhynchus occur in two morphotypes, guild 2 (piercing) and guild 4 (cutting) in Massare's (1987) classification. The dental morphology varies between species and with ontogenetic age to reflect differences in feeding habit. The longirostrine forms $M$. supercilosus and $M$. leedsi, and juveniles of $M$. brachyrhynchus have teeth less flattened in profile. They are considered to be more durophagous in their feeding habits than adults of $M$. brachyrhynchus, whose teeth are relatively more laterally compressed. In both types striations disappear as the tooth ages (Vignaud, 1997). The marks on R54(B) are consistent with the tooth morphology of an adult of $M$. brachyrhynchus.

Martill et al. (1992) reported that Oxford Clay marine crocodiles reveal chemical and isotropic data indicating a surface-dwelling habit in waters of 19 $22^{\circ} \mathrm{C}$. Waters at the bottom of the Oxford Clay sea were at temperatures around $15^{\circ} \mathrm{C}$. This finding does not preclude an occasional dive into deeper water, especially if the reward is a rich food source such as the carcass of a large marine reptile.

Evidence from this specimen of Cryptoclidus extends the range of the diet of Metriorhynchus to include scavenging from carcasses lying on the sea floor. This extends its feeding range below the surface waters, indicating that it was a highly mobile animal capable of exploiting a wide range of feeding sources and habitats.

\section{ACKNOWLEDGEMENTS}

Thanks to the staff of Peterborough Museum and Art Gallery for the loan of the specimen. The marine reptiles team at Leicester Museum - Mark Evans, Arthur Cruickshank and Nick Oliver - contributed much discussion and argument. The helpful comments of the reviewers, David Martill and Darren Naish, made a useful contribution to the final version.

\section{REFERENCES}

Adams-Tresman, S.M. 1987a. The Callovian (middle Jurassic) teleosaurid marine crocodiles from Central England. Palaeontology, 30, 195-206.

Adams-Tresman, S.M. 1987b. The Callovian (middle Jurassic) marine crocodile Metriorhynchus from central England. Palaeontology, 30, 179-194.

Andrews, C.W. 1909. On some new Plesiosauria from the Oxford Clay of Peterborough. Annals of the Magazine of Natural History, 8, 418-429.

Andrews, C.W. 1910. A descriptive catalogue of the marine reptiles of the Oxford Clay. Part $I$. British Museum (Natural History). London.

Andrews, C.W. 1913, A descriptive catalogue of the Marine Reptiles of the Oxford Clay. Part II. British Museum (Natural History). London.

Brown, D.S. 1981. The English Upper Jurassic Plesiosauroidea (Reptilia) and a review of the phylogeny and classification of the Plesiosauria. Bulletin of the British Museum (Natural History), Geology, 35, 253-347.

Cruickshank, A.R.I., Martill, D. \& Noè, L. 1996. A pliosaur (Reptilia, Sauropterygia) exhibiting pachyostosis from the Middle Jurassic of England. Journal of the Geological Society: London, 153, 873-879.

Deslongchamps, E.[.F.G.] 1863\N1869. Notes Paléontologiques. Le Blanc Hardel et Savy, Caen and Paris.

Hua, S. 1994. Hydrodynamique et modalitée d'allègement chez Metrorhychus supercilosus (Crocodylia, Thalattosuchia): Implications paléologique. Neuts Jahrbuch für Geologie und Palaontologie Abhandlungen, 193(I), 1-19.
Martill, D.M. 1986a. The stratigraphic distribution and preservation of fossil vertebrates in the Oxford Clay of England. Mercian Geologist., 10, 161-186.

Martill, D.M. 1986h. The diet of Metriorhynchus, a Mesozoic marine crocodile. Neues Jahrbuch fïr Geologie und Palaontologie, H10, 621-625.

Martill, D.M., Duff, K.L. \& Brown, P.R. 1992. Trophic structure of the Lower Oxford Clay. In (Lidgard, S. \& Crane, P.R.; eds) Fifth North American Paleontological Convention - Abstracts and Program. The Paleontological Society, Special Publications, 6, 200.

Martill, D.M. 1993. Soupy Substrates: A Medium for the Exceptional Preservation of Ichthyosaurs of the Posidonia Shale (Lower Jurassic) of Germany; Kaupia. Darmstädter Beiträge zur Naturgeschichte, 2, 77-97.

Martill, D.M., Taylor, M.A., Duff, K.L., Riding, J.B. \& Brown, P.R. 1994. The trophic structure of the biota of the Peterborough Member, Oxford Clay Formation (Jurassic), UK. Journal of the Geological Society, London, 151, 173-194.

Massare, J.A. 1987. Tooth morphology and prey preference of Mesozoic marine reptiles. Journal of Vertebrate Paleontology. 7, 130-131.

Phillips, J. 1871. Geology of Oxford and the Valley of the Thames. Oxford University Press, Oxford.

Sauvage. H.-E. 1874. Mémoire sur les dinosauriens et les crocodiliens des terrains jurassiques de Boulogne-sur-Mer. Mémoires de la Société Géologique de France, 10(2/2), $1-58$. 
Seeley, H.G. 1869. Index to the Fossil remains of Aves, Ornithosauria, and Reptilia, from the Secondary System of Strata arranged in the Woodwardian Museum of the University of Cambridge. Deighton, Bell \& Co., Cambridge.
Seeley, H.G. 1874. On Muraenosaurus leedsii, a plesiosaurian from the Oxford Clay. Quarterly Journal of the Geological Society of London, 30, 197-203.

Vignaud, P. 1997. La morphologie dentaire des Thalattosuchia (Crocodylia, Mesosuchia). Palaeovertebrata, 26, 35-59.

Manuscript received 17 February 2003; revised typescript accepted 14 May 2003 